\title{
Shallots in Croatia - genetics, morphology and nomenclature
}

\author{
JASNA PUIZINA* \\ University of Split, Faculty of Science, Department of Biology, Teslina 12, 2100 Split
}

\begin{abstract}
The term 'shallot' in Croatia denotes three genetically and morphologically different, vegetatively reproduced relatives of the common onion, Allium cepa L., which are mainly traditionally cultivated for consumption and as a spice: $A$. cepa Aggregatum group, $(2 n=2 x=16)$, A. $\times$ proliferum (Moench) Schrad. $(2 n=2 x=16)$ and A. $\times$ cornutum Clementi ex Vis. $(2 n=3 x=24)$. This paper reviews the results of studies of their morpho-anatomical characteristics and genetic structure. Although all three taxa were determined as varieties of the common onion, only the shallot A. cepa Aggregatum group (syn. A. ascalonicum $\mathrm{L}$.) belongs to that species. The shallot $A . \times$ proliferum represents a hybrid between the two closely related species, A. cepa and A. fistulosum L. The third form of shallot, $A$. $\times$ cornutum is a still incompletely understood triploid hybrid between $A$. cepa and one or two closely related Allium species, whose identity has not been fully elucidated. In contrast to shallot $A$. cepa Aggregatum group, which has normal meiosis and produces fertile seed, hybrid shallots $A . \times$ proliferum and $A . \times$ cornutum are sterile, and reproduce exclusively vegetatively by underground bulbs or bulbils from the inflorescence.
\end{abstract}

Key words: Allium cepa, shallot, hybrid, polyploidy, triploid viviparous onion, top onion, karyotype, genome, meiosis

\section{Common onion, Allium cepa $\mathbf{L}$.}

The genus Allium comprises about 750 species distributed all over the northern hemisphere except for its tropical regions (STEARN 1992, FRITCH and FRIESEN 2002). The common onion is the most widespread and economically important species of the genus Allium (HANELT et al. 1992, FriTCH and FrIESEN 2002). Taxonomically, it belongs to Allium section Cepa (Mill.) Prokh, which consists of twelve species, most of which are used as condiment, vegetable or medicinal plants (GURUSHIDZE et al. 2007).

The common onion is not known in the wild form. Its initial domestication started more than 4000 years ago, probably in the Middle East (HANELT et al. 1992). Several wild relatives of the common onion originate from the mountainous regions of Asia in the region be-

\footnotetext{
* Corresponding, e-mail: puizina@pmfst.hr

Copyright $^{\circledR} 2013$ by Acta Botanica Croatica, the Faculty of Science, University of Zagreb. All rights reserved.
} 
tween South Siberia, the Persian Gulf, and the Caspian Sea (JonES and MANN 1963, HanelT 1992, FRITCH and FRIESEN 2002). However, the wild progenitor(s) and origin of common onion are still not fully understood. Due to their morphological similarities, the wild species Allium oschaninii O. Fedtsch (A. cepa var. silvestre Regel) from Central Asia has been for a long time believed to represent the wild ancestor of the common onion (STEARN 1980, HANELT et al. 1992). This hypothesis was rejected because of different heterochromatic (Giemsa C-banding) patterns of their karyotypes (VosA 1976). Additional experiments also rejected that hypothesis: severe crossing barriers appear between A. cepa and A. oschaninii (VAN RAAMSDONK et al. 1992); the chloroplast phylogeny of the section Cepa placed $A$. oschaninii outside of the clade containing A. cepa (HAVEY 1992). Several recent molecular analysies indicated that the wild species $A$. vavilovii M. Popov et Vved. could be a possible progenitor of A. сера. RFLP analysis of nuclear DNA revealed identical pattern in A. сера and $A$. vavilovii (BRADEEN and HAVEY 1995) and the sequences of three chloroplast loci also indicated a close genetic relationship between $A$. cepa and $A$. vavilovii (VAN RAAMSDONK et al. 2000). One of the main items of evidence suggesting that $A$. vavilovii is a progenitor of the common onion was the phylogenetic study of internal transcribed (ITS) region of the nuclear ribosomal DNA (GURUSHIDZE et al. 2007).

By application of selection and crossings a number of different $A$. cepa forms and varieties have been produced. They can be grown in different climates, on every continent, except in the extreme northern regions and humid tropical and subtropical regions. Red onion cultivars are classified into three groups (BRICKELl et al. 2009, JONES and MANN 1963, FRITCH and FRIESEN 2002): a) Common onion group: underground bulbs are large, flattened at the poles, usually single, inflorescence without bulbils, and reproduction by seeds. This group includes the largest number of commercially produced cultivars, b) Aggregatum group: underground bulbs elongated with numerous lateral bulbs, no bulbils in the inflorescence, either producing seed or else sterile, and reproduction almost exclusively vegetatively, c) Proliferum group: underground bulbs often poorly developed, inflorescence bears bulbils, do not produce seeds and reproduce vegetatively by bulbils in the inflorescence.

The term shallot is most commonly used for a specific variety of A. cepa, and was formerly even classified as a distinct species, A. ascalonicum L. Recent studies have shown that the term shallot in southern Croatia is additionally used for diploid and triploid viviparous onions A. × proliferum (Moench.) Schrad and A. $\times$ cornutum Clementi ex Vis. (PuIZINA $1992,1997)$. This article provides an overview of the results of studies on the morpho-anatomical and genetic structure. A common morphological feature of all three taxa is the vegetative propagation using underground bulbs and a close relationship with the common onion.

\section{Shallot, Allium cepa Aggregatum group}

Shallots had previously been considered a separate species, A. ascalonicum, but today they are classified within the common onion under the currently accepted name $A$. серa Aggregatum group (RABINOwITCH and KAMENETSKY 2002). Besides the best known name A. ascalonicum, there are several other synonyms in use: A. cepa var. aggregatum, A. cepa var. ascalonicum, A. cepa cv. 'Shallot' (JONES and MANn 1963, HANELT et al. 1992, RABINOWITCH and KAMENETSKY 2002). 
Although these plants look morphologically very similar to A. cepa, there are some differences. Plants are perennials and generally have smaller flowers, inflorescences, bulbs and leaves than A. cера. Compared with theleaves of $A$. серa, leaves of shallot are thin, tender, often bent and particularly flat, almost concave on the inner side of the leaves. Underground bulbs are well developed; their shape is oblong, semi-cylindrical. A large number of bulbs are gathered in the clusters. After planting each bulb develops an entire group of side bulbs that are interconnected. Each new bulb develops its own leaves, so that the whole plant has a bushy appearance. In contrast, A. cepa usually has a well-developed stem. The shallot cultivars examined by PuIzINA (1992) had no stamen morphology typical of $A$. cepa (outer anthers simple, interior anthers with an expanded base and one small tooth on each side), but all six stamens were simple (Tab. 1).

All taxa of $A$. cepa Aggregatum group are diploids $(2 n=2 x=16)$ (HANNELT et al. 1992). The structure of the shallot's karyotype could not be distinguished from the karyotype of $A$. cepa. The constitutive heterochromatin as identified by Giemsa C-banding is located mainly at the end of the chromosomes. Only a few interstitial C-bands were identified and their distribution was similar to the distribution of Giemsa C-banding in A. cepa (Figs. 4a, b) (Vosa 1976, PUIZINA 1992). In meiosis eight bivalents are regularly seen in diakinesis and metaphase I (Fig. 5d). Bivalents have terminal type of chiasmata and are generally of the same shape as A. cepa bivalents (rings and rods) (Fig. 5a). The plant rarely produces flowers although the pollen is fertile and a seed is produced. It is mainly propagated vegetatively by dividing and planting underground bulbs.

On a global scale, the shallot, A. cepa Aggregatum group, is a minor Allium crop. However in South East Asia and some African countries where onion seed is hard to produce, where onion culture is difficult and where the growing season is too short for the production of bulb onion, the vegetatively propagated shallot is cultivated as an important substitute for bulb onion (RABINOWITCH and KAMENETSKY 2002). The relationship of shallots to common onion was investigated by application of Random Amplified Polymorphic DNA (RAPD) markers and morphological traits (LE THIERRY D'ENNEQUIN et al. 1997). Sexually propagated shallots were more closely related to common onion than the vegetetively propagated shallots, which grouped separately. The grey shallot is a specific form of shallots long cultivated in France and Italy. MAASS (1996) compared the isozyme profile of 30 accessions of the French grey shallot, with those of 466 bulb onions and other shallots, 15 accessions of A. oschaninii and 22 accession of $A$. vavilovii. The results suggested that the French grey shallots differ from other shallots and were more closely related to either to A. oschaninii or A. vavilovii, that to A. cepa and other shallots. According to the RAPD analysis and GISH results, FRIESEN and KLAAS (1998) also concluded that grey shallots belong to A. oschaninii.

\section{Shallot, Allium $\times$ proliferum $($ Moench) Schrad.}

In the local dialect of South Croatia, there are several different names for this shallot: kozjak, orijaš, škalonja, ljutika, ljutika-talijanka (PUIZINA and PAPEŠ 1999). The diploid viviparous onion is also known as top onion, tree onion or Egyptian onion. Previously it has been classified as a variety of common onion A. cepa var. proliferum (Targioni, Tozzetti) or A. cepa var. viviparum (Metzg.) Alef. (Helm 1956, Jones and Mann 1963, McCollum 1974, PUIZINA and PAPEŠ 1996). Since plants represent a spontaneous hybrid between $A$. cepa (common onion) and A. fistulosum (Japanese bunching onion), ScHUBERT et al. (1983) 


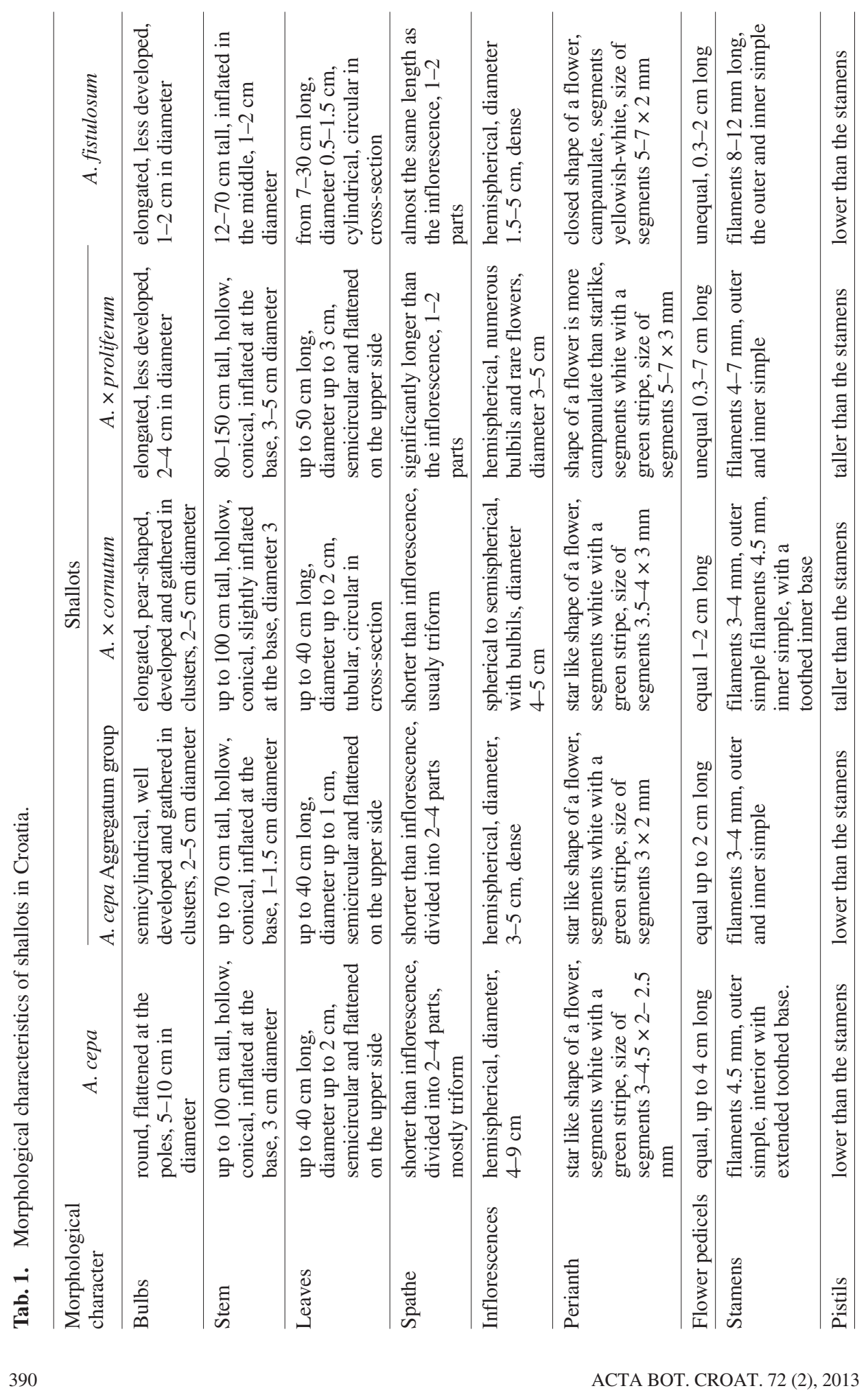


pointed out that for nomenclatural reasons this onion should be named $A . \times$ proliferum (Moench) Schrad.

Plants have a relatively poorly developed bulb, similar to the parental species $A$. fistulosum. A sort of gigantism that characterizes this cultivar is its most striking feature, in which it also differs from other varieties of onions. Due to the rapid vegetative development, these perennial plants can grow up in height up to $130 \mathrm{~cm}$, and their flower pedicels can be 3-5 cm long. Their inflorescences regularly contain flower bulbils with some sterile flowers. Bulbils often sprout within the transformed umbel (Figs. 1c, f), sometimes in two or more tiers. With respect to the shape and structure of the stamen's filaments, the plant more closely resembles A. fistulosum. Specifically, the shape of the flower is more campanulate and closed as in A. fistulosum, rather than stellar and open as in A. серa. Stamen filaments are long, thin, without or with barely noticeable expansion on the basis of internal stamens. Anthers are often rudimentary or sterile (Fig. 2d). Given the form of leaf, this type of shallot resembles A. cepa (flattened on the inner side). A special feature of this shallot is the long spathe that envelops the inflorescence, which it surmounts considerably.. This novel feature is not characteristic of A. cepa or A. fistulosum. As the underground bulbs are poorly developed, and the plant does not produce seeds, plants mostly reproduce vegetatively by bulbils from the inflorescences (usually $4-8$ bulbils per inflorescence).
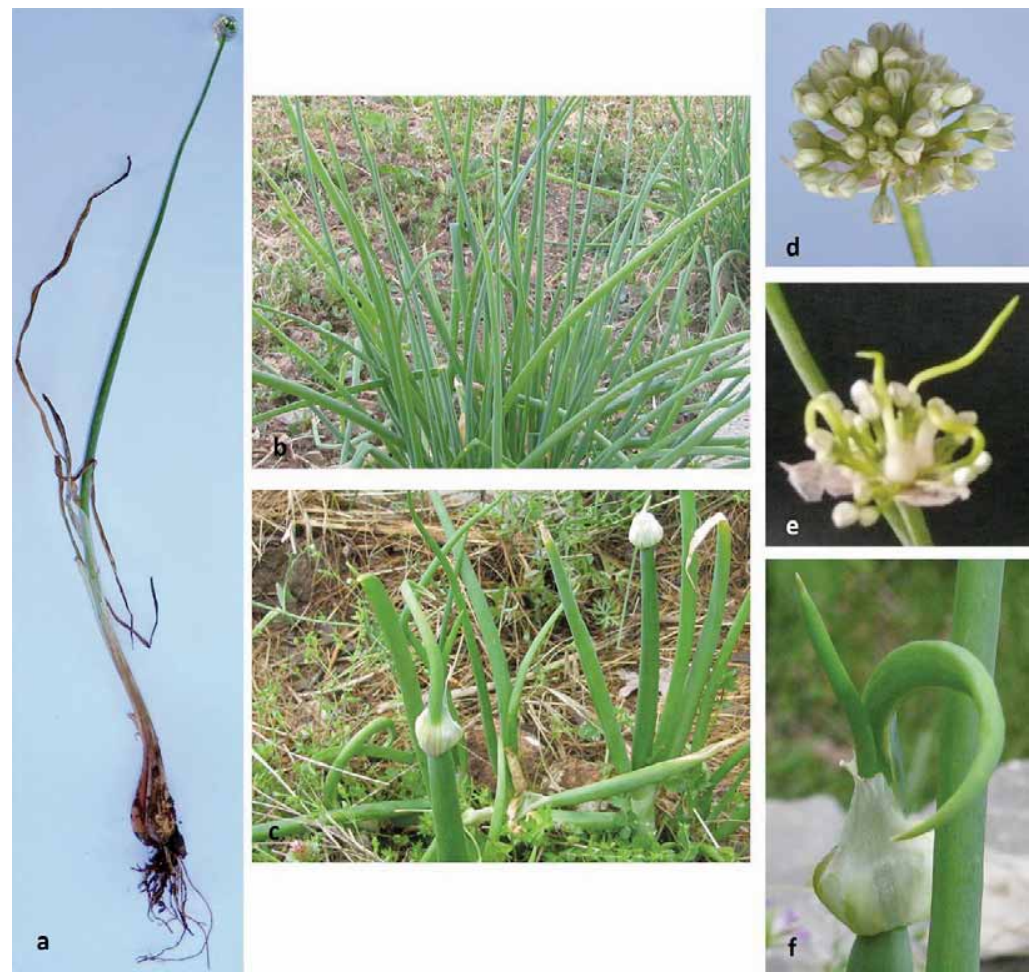

Fig. 1. Allium $\times$ cornutum: $\mathbf{a}$ - appearance; $\mathbf{b}$ - plants in the soil; $\mathbf{d}$-young inflorescence, $\mathbf{e}$ - mature inflorescence carrying two bulbils which are already sprouting. Allium $\times$ proliferum: $\mathbf{c}-$ plants in the soil; $\mathbf{f}$ - bulbils often sprout within the transformed inflorescence before its opening. 
Top onions, $A . \times$ proliferum, are a vegetatively propagated garden crop in Europe, North East Asia and North America. Several karyological studies indicated its hybrid (allodiploid) nature and showed that the karyotype consists of one haploid A. cepa and one haploid $A$. fistulosum set of chromosomes (BOZZINI 1964, McCOLLUM 1974, FISKESJO 1975, SCHUBERT et al. 1983, PUIZINA and PAPEŠ 1999). Chromosomes preserved their original C-banding pattern as in the parental species with the exception of $A$. cepa satellite chromosome that lost its satellite (Fig. 4d). Meiosis of $A$. $\times$ proliferum is characterized by chromosome pairing of nonhomologous chromosomes into heterobivalents (Fig. 5d). However, univalents were frequently seen and very rarely some multivalents. Bivalents with terminally located chiasmata dominate, but occasionally bivalents with localized chiasmata (near the centromere) can be seen (PUIZINA 1997). The hybrid origin has been proved by isozyme analysis (MAASS 1997a), RAPD markers (FRIESEN and KLAAS 1998) as well as by genomic in situ hybridization (GISH) experiments using labeled total genomic DNAs from A. cepa and A. fistulosum as probes. Each probe labeled one genome (eight chromosomes of top onion; FRIESEN and KLAAS 1998, PUIZINA and PAPEŠ 1999). Allium wakegi Araki is a sexually sterile ancient garden crop in Japan and China. Its hybrid nature $(A$. cepa $\times$ A. fistulosum) has been confirmed by GISH and by localization of $5 \mathrm{~S}$ rRNA loci at chromosomal positions corresponding to $A$. cepa and A. fistulosum (HizUME 1994).

\section{Shallot, Allium $\times$ cornutum Clementi ex Vis.}

The triploid shallot is traditionally cultivated in South and coastal Croatia under the name 'Ljutika' and it is very popular as a spice and condiment due to its tasty bulbs and leaves. It was first named A. cepa var. viviparum (LANGER and Koul 1983; PuIzINA and PAPEŠ 1996, 1997), but FRIESEN and KLAAS (1998) suggested that this name is connected with the other viviparous onion $A . \times$ proliferum and proposed using the name $A$. cornutum
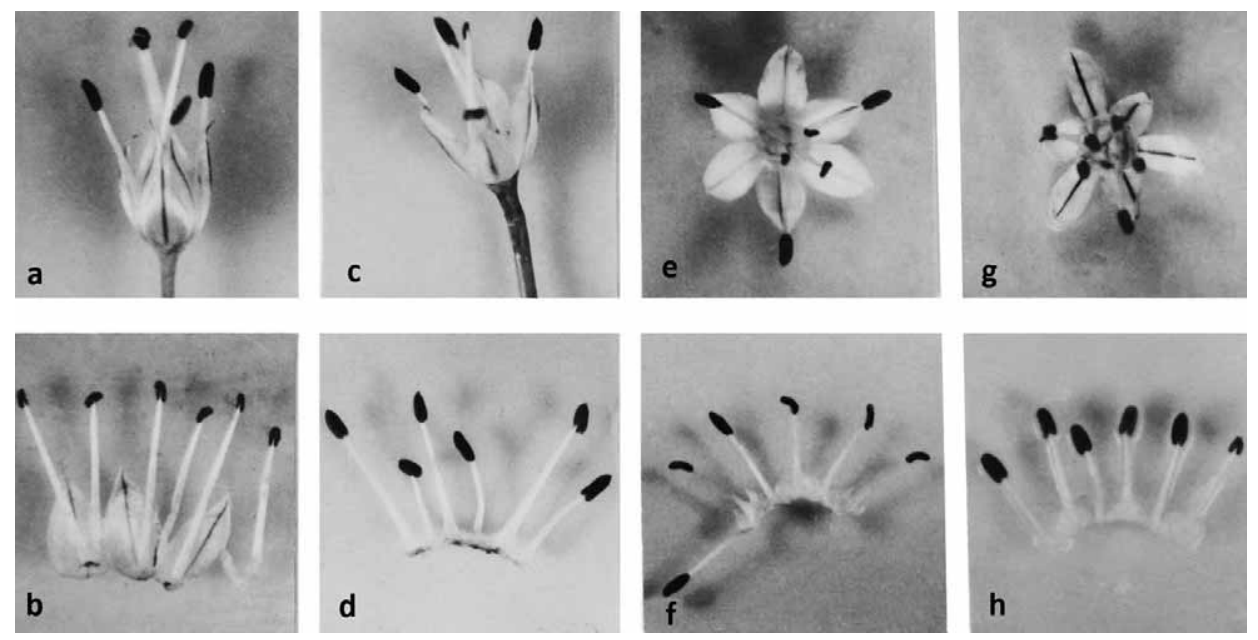

Fig. 2. Flower and stamen morphology: a, b-A. fistulosum; c, $\mathbf{d}-A . \times$ proliferum $; \mathbf{e}, \mathbf{f}-A . \times$ cornutum; $\mathbf{g}, \mathbf{h}-A$. сера. In contrast with $A$. серa, which is characterized by the broadened base of the inner filament $(\mathrm{h})$, the triploid A. $\times$ cornutum possesses rather pronounced triangular teeth at the bases of the inner filaments (f). 
Clementi ex Vis. (VISIANI 1842), the only name which is unambiguously connected with the triploid onion (STEARN 1980, MAASS 1997b). However, taking into account its hybridogenic origin, it was modified to: A. $\times$ cornutum. Interestingly, this name was first used by VISIANI (1842) for a Dalmatian bulbiferous taxon, which was observed for the first time on the rocks of Dubrovnik (STEARN 1980).

In contrast to most flowering species of Allium in which the leaves are already dying back at flowering time, triploid shallots are perennials, their leaves remain green and suitable for use during entire year. It blooms, like the majority of other Allium species, from May and June. Plants are sterile and do not produce seeds. They propagate vegetatively by underground bulbs and bulbils from inflorescence. Phenotypically, triploid shallots (viviparous onions) closely resemble $A$. cepa, and sometimes it is difficult to distinguish them if they are planted both in the soil, before developing their inflorescences (Figs. $1 \mathrm{a}, \mathrm{b}$ ). The triploid shallot's flower is star-shaped; the segments are white with a green stripe. Three inner stamens have a broadened base with two prominent teeth (one from each side) (Figs. 2e, f). Outer stamens are simple. Inflorescences of the triploid shallot initially contain only the flowers, which are by their dimensions slightly larger than the flowers of $A$. cepa and generally les numerous in the inflorescence than in A. cepa (Figs. 1a, 3a). During the maturation of inflorescences, small reproductive bulbils begin to appear (Figs. 1d, e) and flowers gradually disappear. At the end, the mature inflorescence is composed only of the bulbils (up to 20-30 bulbils per inflorescence). It has never been noticed that bulbils from the inflorescence develop their own stems and inflorescences, which is a regular case in the diploid hybrid shallot, while occasionally triploid bulbils from the inflorescences develop only a few leaves (Fig. 1e).

These small reproductive bulbils, which regularly develop among sterile flowers in the inflorescence of the triploid shallot are a reliable sign for its recognition, as they never develop in the diploid A. сера. Another reliable sign of the triploid shallot as against A. серa are the elongated underground bulbs (Fig. 1a). Bulbs are gathered in large numbers, sometimes 10-20 or more individual bulbs are held together by the same basal plate. From each bulb leaves emerge and the plant has a bushy form. The triploid shallot can also be distinguished from A. cepa with respect to the shape of leaves. Leaves are not semicircular and flattened on one side as they are in $A$. серa, nor are they round in shape. They are intermediate between the semicircular and the round shape. The stalk that bears the inflorescence is only slightly flattened at the bottom, whereas the stalk in A. cepa is inflated at the base of the stem.

The triploid shallot does not exhibit the same effect of gigantism as top onions. It is even slightly smaller than the diploid A. cepa (they grow up to $100 \mathrm{~cm}$ ). Although its bulbs and leaves are very tasty and are used in the diet, there is a problem of their prolonged storage and keeping after harvesting, because they tend to rather quickly produce new leaves and roots, thus losing weight. That is probably the reason why the bulbs are usually kept by being preserved in vinegar.

The karyotype of $A . \times$ cornutum $(2 n=3 x=24)$ consists of 24 chromosomes (SINGH et al. 1967, PUIZINA and PAPEŠ 1996). The homology between the chromosomes is weak and occasional, and it is very difficult, and even impossible, to identify homologous pairs of chromosomes. Therefore the chromosomes are usually lined up with respect to size. The exceptions are the three subtelocentric chromosomes, which are put at the end of the karyotype (Figs. 3a, b). The most common chromosome associations in diakinesis and metaphase I of 

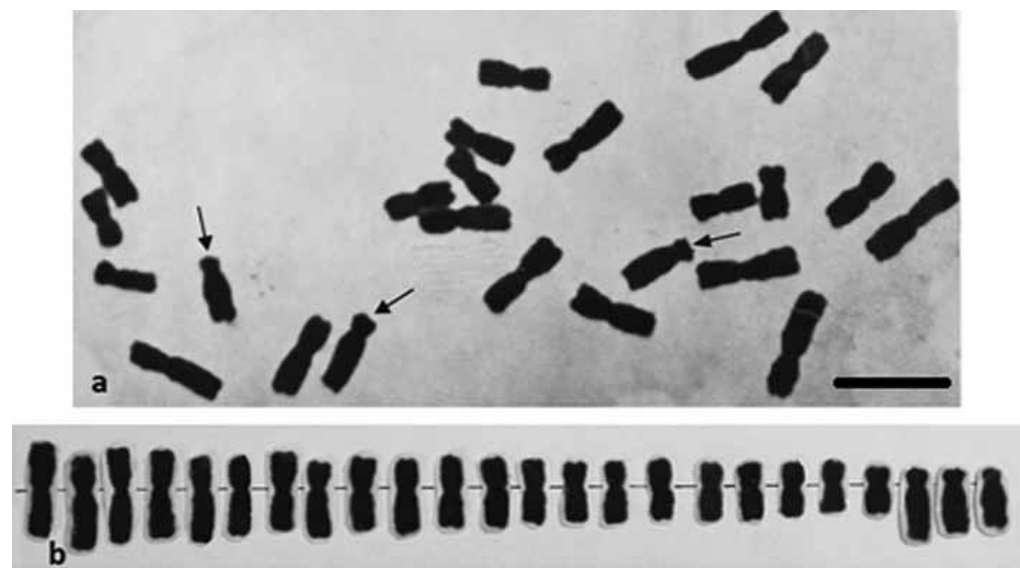

Fig. 3. Mitotic chromosomes of root tip cells in A. $\times$ cornutum (a), $2 n=3 x=24$, stained by Feulgen. Arrows indicate the three satellite schromosomes. Chromosomes aligned in the kariogram (b). Scale bar $=10 \mu \mathrm{m}$.

A. $\times$ cornutum are heterotrivalents, which suggests a partial homology of the three genomes (PUIZINA and PAPEŠ 1997). Additionally, the frequent occurrence of complex multivalents was observed (4-11 paired chromosomes) suggesting that intergenomic pairing, translocations and chromosomal rearrangements were involved in the evolution of the triploid karyo-

A. cepa
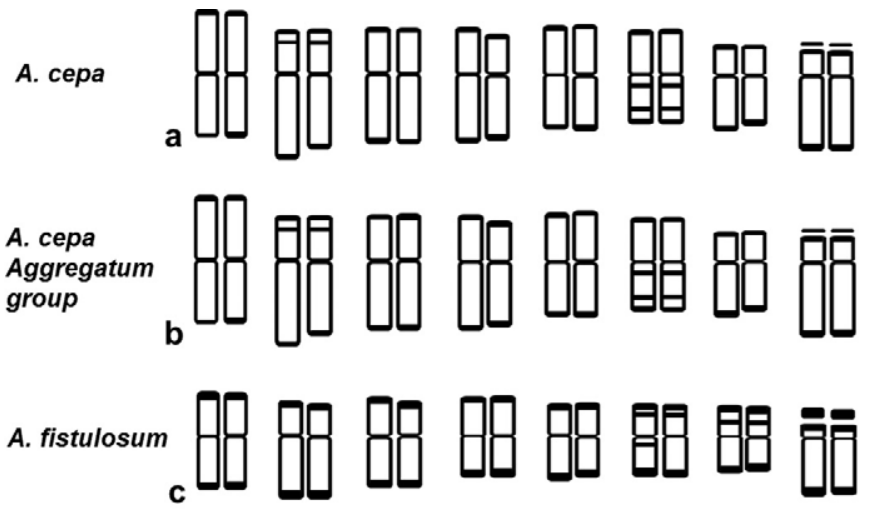

A. x proliferum

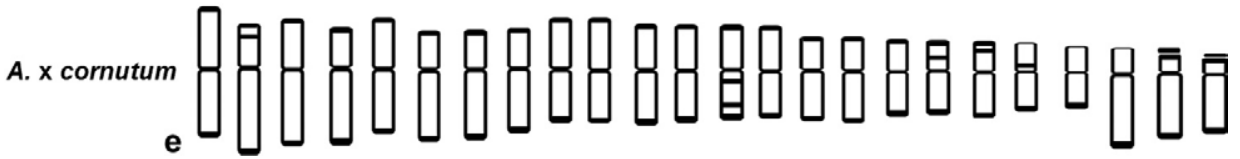

Fig. 4. Schematic representation of Giemsa C-banding karyotypes in shallots. 
type (Fig. 5e). Identification of the constitutive heterochromatin by Giemsa and fluorochrome banding in the karyotype of $A$. x cornutum (LEPEN and PUIZINA 2011) indicated the hybrid structure of the karyotype, which contained only one genome originating from $A$. cepa (Fig. 4e). Previously, triploid viviparous onions have been suspected to be either an allotriploid (AAB) (SINGH et al. 1967), or a segmental allotriploid (AA'A") (Koul and GoHIL 1971). The chloroplasts DNA (cpDNA), the nuclear fragment of rRNA genes and the RAPD molecular markers indicated A. cepa as one parent (HAVEY 1991, 1992, 1993; KLAAS and FRIESEN 2002).

In order to determine the parental Allium species of A. $\times$ cornutum, genomic fluorescent in situ hybridization (GISH) was applied (PuIZINA et al. 1999). Biotinylated genomic DNAs from six diploid Allium species (A. cepa, A. fistulosum, A. roylei Stearn, A. vavilovii, A. galanthum Kar. et Kir. and $A$. oschaninii) were used as probes. While probes obtained from genomic DNA of A. cepa, A. vavilovii and A. roylei hybridized to somatic chromosomes of A. $\times$ cornutum, probes from A. fistulosum, A. galanthum, and A. oschaninii did not. The DNA probes of $A$. cepa and $A$. roylei each completely or predominantly labeled one genome (eight chromosomes). A few chromosomes, the markers of the triploid karyotype, were not completely labeled by any of the probes applied. These GISH results indicated that triploid viviparous onions might possess a complex triparental genome organization (PUIZINA et al. 1999). Using a similar approach FRIESEN and KLAAS (1998) reached a different conclusion. They could verify only $A$. cepa as a parental species and according to these authors, the majority of DNA and chromosomes of A. $\times$ cornutum originate from A. cepa.

Further progress in the identification of the parental species of $A$. $\times$ cornutum, an 'enigmatic plant' as noted by KLAAS and FRIESEN (2002), was hampered by the lack of more molecular data about wild relatives of common onion as well as suitable molecular markers. Recently, the ITS sequences (internal transcribed spacer of the 18S-5.8S-26S rDNA) of large number of common onion relatives originating from Central Asia, were deposited in GenBank (GuRUSHIDZE et al. 2007) as well as the sequences of the 5S rRNA (SoN et al.
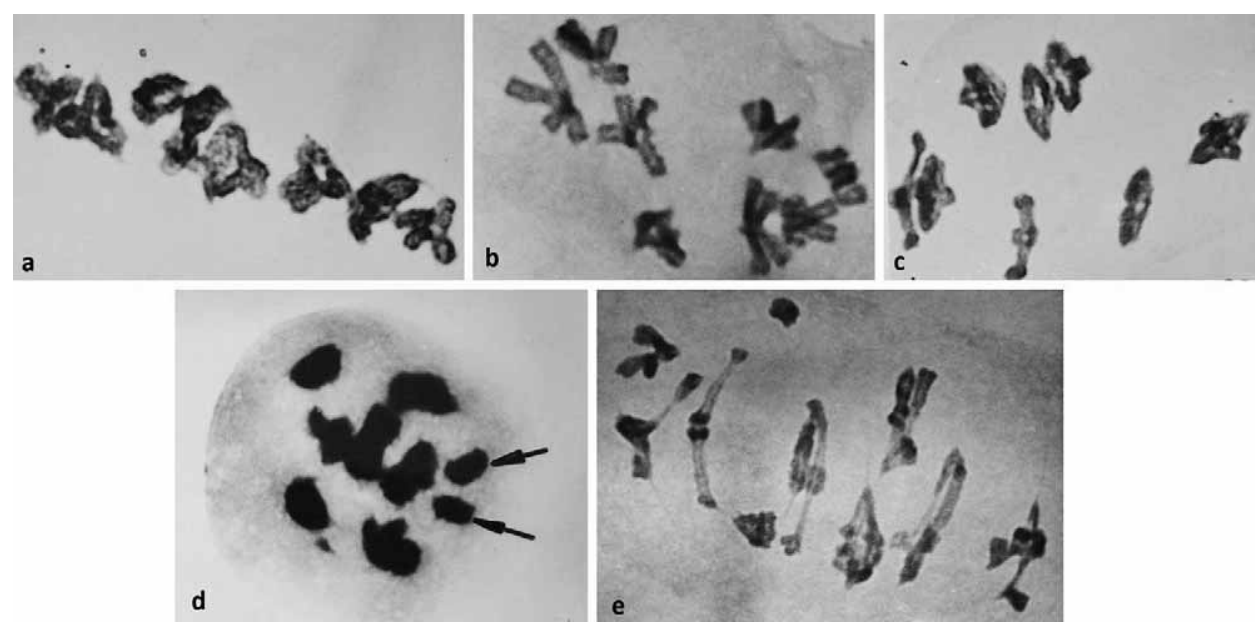

Fig. 5. Meiosis, metaphase I: a-Allium cepa; $\mathbf{b}-$ A. fistulosum; $\mathbf{c}-$ A. cepa Aggregatum group; $\mathbf{d}-$ A. $\times$ proliferum $; \mathbf{e}-$ A. $\times$ cornutum. 
2012). Our preliminary results detected several types of ITS and 5S rRNA sequences in $A . \times$ cornutum. Detailed analysis of these sequences is in progress and the results achieved will help us to understand the origin and the genome structure of that interesting triploid hybrid better.

The triploid viviparous shallot $A . \times$ cornutum is a rather widespread garden crop in South-East Asia, Europe and other parts of the world. Based on several morphological, cytogenetic and molecular studies, it is now recognized as a separate Allium crop and a new taxonomic unit. Since almost all its clones are practically identical (MAASS 1997b, FRIESEN and KLAAS 1998, PUIZINA et. al 1999), the monophyletic origin of this widely distributed crop is likely, and northern India (Kashmir) might be the place of origin. Although humans must have contributed to the maintenance and spread of this vegetatively reproduced crop, findings of $A . \times$ cornutum in abandoned vineyards and other less-favored agricultural and even landfill areas suggest that this plant is very tolerant to drought and poor soil and is able to persist even in wild habitats.

\section{Acknowledgements}

This work received funding from the Croatian Ministry of Science, Education and Sport through a grant to Jasna Puizina (no. 177-11911196-0829). Author thanks to Dr. Juraj Kamenjarin and Dr. Mirko Ruščić for providing pictures of shallots. The author also thanks the two anonymous reviewersfor their helpful suggestions and comments, which improved the final version of the manuscript.

\section{References}

BozzINI, A., 1964: On the karyotype of a viviparous onion known as Allium cepa var. viviparum (Metzg.) Alef. Caryologia 17, 459-464.

BRADEEN, J. M., HAVEY, M., 1995: Restriction fragment length polymorphisms reveal considerable nuclear divergence within a well-supported maternal clade in Allium section Cepa (Alliaceae). American Journal of Botany 82, 1455-1462.

Brickell, C. D., Alexander, C., David, J. C., Hetterschleid, W. L. A., Leslie, A. C., Malecot, V., XiAobai, J., 2009: International code of nomenclature for cultivated plants. Scripta Horticulturae 10, 1-184.

FiSKESJO, G., 1975: Chromosomal relationships between three species of Allium as revealed by C-banding. Hereditas 81, 23-32.

FRIESEN, N., KLASS, M., 1998: Origin of some minor vegetatively propagated Allium crops studied with RAPD and GISH. Genetic Resources and Crop Evolution 45, 511-523.

FrITCH, R. M., FrIESEN, N., 2002: Evolution, domestification and taxonomy. In: RABINOwITCH, H. D., UrRaH, L. (eds.), Allium Crop Science, 5-30. Recent advances, CABI Publishing, CAB International, Wallingford Oxon OX108DE, UK.

Gurushidze, M., Mashayekhi, S., Blattner, F. R., Friesen, N., Fritsch, R. M., 2007: Phylogenetic relationship of wild and cultivated species of Allium section Cepa inferred by nuclear rDNA ITS sequence analysis. Plant Systematics and Evolution 269, 259-269.

Hanelt, P., Schultze-Motel, J., Fritsch, R., Kruse, J., MaAss, H. I., Ohle, H., Pistrick, K., 1992: Infrageneric grouping of Allium - the Gatersleben approach. In: Hanelt, P., 
Hammer, K., KnupfFer, H., (eds.), The Genus Allium, 107-123. Proceedings of the International Symposium on Taxonomic Problems and Genetic Resources, Gatersleben.

HAVEY, M. J., 1991: Molecular characterization of the interspecific origin of viviparous onion. Journal of Heredity 82, 501-503.

HAVEY, M. J., 1992: Restriction enzyme analysis of the chloroplast and nuclear 45s ribosomal DNA of Allium sections Cepa and Phyllodolon (Alliaceae). Plant Systematics and Evolution 183, 17-31.

Havey, M. J., 1993: A putative donor of S-cytoplasm and its distribution among open-pollinated populations of onion. Theoretical and Applied Genetics 86, 128-134.

Helm, J., 1956: Die zu Wurz und Speisezwecken Kultivierten Arten den Gattung Allium L. Kulturpflanze 4, 130-180.

Hizume, M., 1994: Allodiploid nature of Allium wakegi Araki revealed by genomic in situ hybridization and localization of $5 \mathrm{~S}$ and $18 \mathrm{~S}$ rDNAs. Japanese Journal of Genetics 69 , 407-415.

Jones, H. A., MAnN, L. K., 1963: Onions and their allies. Leonard Hill Books Ltd., New York.

Koul, A. K., GoHIL, R. N., 1971: Further studies on natural triploidy in viviparous onions. Cytologia 36, 253-261.

KlaAs, M., Friesen, N., 2002: Molecular markers in Allium. In: Rabinowitch, H. D., Currah, L. (eds.), Allium Crop Science, 5 - 30. Recent advances, CABI Publishing, CAB International, Wallingford Oxon OX108DE, UK.

LANGer, A., Koul, A. K., 1983: Studies on nucleolus and nucleolar chromosomes in angiosperms, VII. Nature of nucleolar chromosome polymorphism in Allium cepa var. viviparum (Metzg.) Alef. Cytologia 48, 323-332.

LEPEN, I., PUIZINA, J., 2011: FISH mapping of 18S-5.8S-26S rRNA genes and fluorochrome banding in the triploid viviparous onion Allium $\times$ cornutum Clementi ex Visiani, 1842. Acta Biologica Cracoviensia Series Botanica 53, 111-116.

Le Thierry D'Ennequin, M., Panaud, O., Robert, T., Ricroch, A. 1997: Assessment of genetic relationships among sexual and asexual forms of Allium cepa using morphological traits and RAPD markers. Heredity 78, 403-409.

MAass, H. I., 1996: About the origin of the French gray shallot. Genetic Resources and Crop Evolution 43, 291-292.

MaAss, H. I., 1997a: Genetic diversity in top onion, Allium x proliferum, analysed by isozymes. Plant Systematics and Evolution 208, 35-44.

MaASS, H. I., 1997b: Studies on triploid viviparous onions and their origin. Genetic Resources and Crop Evolution 44, 95-99.

McCollum, G. D., 1974: Hybrid origin of top onion, Allium cepa var. viviparum. Zeitschrift für Pflanzenzüchtung 71, 222-232.

Pignati, S., 1982: Flora d'Italia 3. Edagricole, Bologna.

PuizINA, J., 1992: Cytogenetic evidences of hybrid structure and origin of diplod and triploid shallot (Allium cepa var. viviparum, Liliaceae) from Dalmatia (Croatia). MSc. Thesis, University of Zagreb, Zagreb. 
PuIzINA, J., 1997: Cytogenetic and molecular characteristics of natural hybrids and polyploids of red onion (Allium cepa L.). PhD. Thesis, University of Zagreb, Zagreb.

PUIZINA, J., PAPEŠ, D., 1996: Cytogenetical evidence for hybrid structure and origin of diploid and triploid shallots (Allium cepa var. viviparum, Liliaceae) from Dalmatia (Croatia). Plant Systematics and Evolution 199, 203-215.

PuIZINA, J., PAPEŠ, D., 1997: Further cytogenetic analyses of the Croatian triploid shallot »Ljutika« (Allium cepa var. viviparum, Alliaceae) and its comparison with the Indian triploid »Pran«. Plant Systematics and Evolution 208, 11-23.

PuizinA, J., PAPEš, D., 1999: Classical and molecular cytogenetic studies of top onion, Allium $\times$ proliferum $($ Moench) Schrader. Acta Botanica Croatica 58, 65-77.

Puizina, J., Javornik, B., Bohanec, B., Schweizer, D., Maluszynska, J., PAPEš, D., 1999: Random amplified polymorphic DNA analysis, genome size, and genomic in situ hybridization of triploid viviparous onions. Genome 42, 1208-1216.

Rabinowitch, H. G., KAmENETSKy, R. 2002: Shallot (Allium cepa Aggregatum Group). In: Rabinowitch, H. D. (ed.), Currah L. (eds.), Allium Crop Science, Recent advances, 5-30. CABI Publishing, CAB International, Wallingford Oxon OX108DE, UK.

Schubert, I., Ohle, H., Hanelt, P. 1983: Phylogenetic conclusions from Giemsa banding and NOR staining in top onions (Liliaceae). Plant Systematics and Evolution 143, 245-256.

Singh, F., Ved Brat, S., Khoshoo, T. N., 1967: Natural triploidy in viviparous onions. Cytologia 32, 403-407.

Son, J. H., PARK, K. C., LeE, A. I., JeOn, E. J., Kim, H. H., Kim, N. S., 2012: Sequence variation and comparison of the 5S rRNA sequences in Allium species and their chromosomal distribution in four Allium species. Journal of Plant Biology 55, 15-25.

Stearn, W. T., 1980: Allium L. In: Tutin T. G., Heywood, V. H. (eds.), Flora Europaea 5. University Press, Cambridge.

STERN, W. T., 1992: How many species of Allium are known? Kew Magzine 9, 180-182.

VAn RAAmsdonk, L. W. D., De VRIES, T., 1992: Biosystematic studies in Allium L. section Cepa. Botanical Journal of the Linnean Society 109, 131-43.

van RaAmsdonk, L. W. D., VRielinK-VAn Ginkel, M., KiK, C., 2000: Phylogeny reconstruction and hybrid analysis in Allium subgenus Rhizirideum. Theoretical and Applied Genetics 100, 1000-1009.

Schlosser, J. C., FARKAŠ-Vukotinović, L., 1869: Flora Croatica, Zagreb

VISIANI, R., 1842: Flora Dalmatica 1. Hofmeister, Lipsiae.

VosA, C. G., 1976: Heterochromatic patterns in Allium. The relationship between the species of the Cepa group and its allies. Heredity 36, 383-392. 